\title{
Abdominal Wall Actinomycosis Associated with Foreign Body Perforation
}

\author{
Karol Sieniawski ${ }^{1}$, Anna Kreisel', Krzysztof Kaczka', Agnieszka Wierzchniewska-tawska ${ }^{2}$, Lech Pomorski', \\ Jacek Smigielski ${ }^{1,3}$
}

'Department of General and Oncological Surgery, Medical University of Lodz, Poland

2Department of Pathomorphology, Medical University of Lodz, Poland

${ }^{3}$ Department of Military Surgery, Medical University of Lodz, Poland

${ }^{*}$ Corresponding author:

Karol Sieniawski, MD

Department of General and Oncological Surgery, University Hospital and

Education Centre of Medical University of Lodz, Pomorska St. 251, 92-213

Lodz, Poland

E-mail: sieniawski@vp.pl

\section{Rezumat \\ Actinomicoză de perete abdominal asociată perforatiei intestinale prin corp străin}

Actinomicoza peretelui abdominal este o infecție foarte rară cauzată de o bacterie Gram-pozitivă anaerobă, respectiv de Actinomyces. Acest articol expune cazul unei paciente în vârstă de 72 de ani, ce prezintă durere cronică localizată în hipocondrul drept şi o formațiune pseudotumorală apărută la nivelul peretelui abdominal anterior de aproximativ 6 luni. S-au efectuat o ecografie abdominală şi o tomografie computerizată (CT) abdominală care au evidențiat prezența unui proces inflamator în cadranul abdominal superior drept. Formațiunea pseudotumorală a fost localizată în grosimea muşchiului drept abdominal, fiind extinsă şi la nivelul organelor intra-abdominale şi al țesutului subcutanat. Se decide intervența chirurgicală şi se practică excizia tumorii împreună cu rezecția parțială a colonului transvers. Examenul histopatologic a stabilit diagnosticul de formațiune tumorală inflamatorie (actinomicoză) consecutivă perforației intestinale prin corp străin (os de peşte). Pacientul a primit postoperator antibioterapie (penicilină) şi a fost externat în a 11-a zi după operație.

Cuvinte cheie: Actinomyces, corp străin, perforație, intervenție chirurgicală, actinomicoză a peretelui abdominal 


\begin{abstract}
Abdominal wall actinomycosis is a very rare infection caused by anaerobic Gram-positive bacteria Actinomyces. We present a case of a 72-year-old female with chronic pain located in the right hypochondriac region and anterior abdominal wall mass which had developed six months before. An ultrasonography (USG) and computed tomography (CT) scan of the abdomen were performed and showed an inflammatory change with a strong internal linear reflection in the right upper abdomen. The tumor was located inside the rectus abdominis muscle and connected with internal organs and subcutaneous tissue. The patient qualified for surgery. En block tumor excision was made with partial resection of the transverse colon. Postoperative study revealed fishbone-associated inflammatory actinomycosis tumor. The patient was successfully managed postoperatively with penicillin and discharged on the $11^{\text {th }}$ day after the surgery.
\end{abstract}

Key words: Actinomyces, foreign body, perforation, surgery, abdominal wall actinomycosis

\section{Introduction}

Foreign body ingestion is relatively frequent. This problem commonly affects children, mentally retarded patients or patients with psychiatric disorders, people abusing alcohol and prisoners. The majority of those events are asymptomatic. However, swallowing of sharp objects increases the likelihood of complications, such as perforation up to $35 \%$ (1). Only two cases reported remote migration of ingested foreign bodies to the abdominal wall $(2,3)$. Clinical manifestations are various and depend on the localization of the perforation. The most common symptom is abdominal pain and it can be misdiagnosed as different disorders such as: peptic ulcer perforation, acute appendicitis, cholecystitis, diverticulitis (4). Patient history may not help to determine the diagnosis because a large number of individuals is not aware of foreign body ingestion. The perforation of a gastrointestinal tract frequently progresses to internal bacterial infection.

The Actinomyces spp. are filamentous Gram-positive anaerobic bacteria that frequently exist inside human organisms. They can be isolated from the oropharynx, gastrointestinal tract, and female genitalia. Specific factors such as poor oral hygiene, local tissue damage, immunosuppression, malnutrition, diabetes mellitus can induce a chronic, suppurative, fibrosing infection called actinomycosis. It has been estimated that the risk of morbidity ranges from $1 / 300000$ to $1 / 1000000$ (5). The most common region of infection is the cervicofacial area (50\%), less frequently abdominopelvic (20\%), and thoracic (15\%) areas (6). The majority of abdominal actinomycosis affects the ileocecal area, the appendix predominating. In $65 \%$ of abdominopelvic actinomycosis it is caused by perforated appendix (5). Other localizations such as colon, anorectum, liver, biliary system, abdominal wall are also possible. Colonic or abdominal wall actinomycosis are rather infrequent clinical forms. The left side of the colon is most commonly involved. In such cases, infection is caused by generalized pelvic actinomycosis after intrauterine contraceptive device (IUCD) insertion. In addition, isolated abdominal wall lesions are frequently connected with concomitant pelvic infection (7).

We report a case of actinomycosis of the anterior abdominal wall caused by perforation of the transverse colon near a hepatic flexure by a fishbone in a 72-year-old woman. The patient had previously been misdiagnosed as a cholecystitis.

\section{Case Report}

A 72-year-old woman complained of chronic right upper quadrant pain that started six 
months before. Medical history included type 2 diabetes mellitus, gout, hypercholesterolemia, hypertension. Abdominal ailment occurred during Christmas. According to the patient it was caused by improper diet. The woman did not recall any injury to the abdomen. Two weeks after the onset of pain, the woman presented to the emergency room in a local hospital where routine laboratory evaluation and USG of the abdomen were conducted. No abnormal findings were reveled. Surgical consultation also took place. The patient received analgesic and antispasmodic medicines and symptoms decreased. The woman was discharged from the hospital with recommendation for further treatment on an outpatient basis. During the next six months a right upper quadrant pain did not subside. Her general practitioner repeated basic blood tests and USG of abdomen. No specific cause for the patient's symptoms was found.

Two weeks later, the patient presented to our clinic. Physical examination revealed a palpable tender mass in the right hypochondriac region suggesting acute cholecystitis. A complete blood cell count revealed $9.9 \times 10^{3} / \mu \mathrm{L}$ white cells, $4.48 \times 10^{6} / \mathrm{\mu L}$ red cells, $424 \times 10^{3} /$ $\mu \mathrm{L}$ platelets, $69.7 \%$ neutrocytes, and $22.8 \%$ lymphocytes. Pertinent serum chemistries showed: a C-reactive protein (CRP) level of $14.1 \mathrm{mg} / \mathrm{L}$ (normal $<6 \mathrm{mg} / \mathrm{L}$ ), total bilirubin level of $0.4 \mathrm{mg} / \mathrm{dL}$ (normal: $0.29 \sim 1.23 \mathrm{mg} / \mathrm{dL}$ ), amylase level of $47 \mathrm{U} / \mathrm{L}$ (normal: 22 80 U/L), respectively, and an aspartate transaminase (AST) level of $24 \mathrm{U} / \mathrm{L}$ (normal: 0 31 U/L), alanine transaminase (ALT) level of $8 \mathrm{U} / \mathrm{L}$ (normal: 0 34 U/L). USG of the abdomen showed a hypoechogenic inflammatory mass with central linear echo inside the anterior abdominal wall. A contrast-enhanced CT of the abdomen and pelvis showed an abdominal wall inflammatory collection with linear foreign body $40 \times 2 \times 3 \mathrm{~mm}$ sized. The inflammatory lesion was conducting through the rectus abdominis muscle to the right lobe of the liver and the transverse colon (Fig. 1). After consideration of the clinical picture, a surgical approach was adopted. An exploratory laparotomy was conducted. A tumor infiltrating an

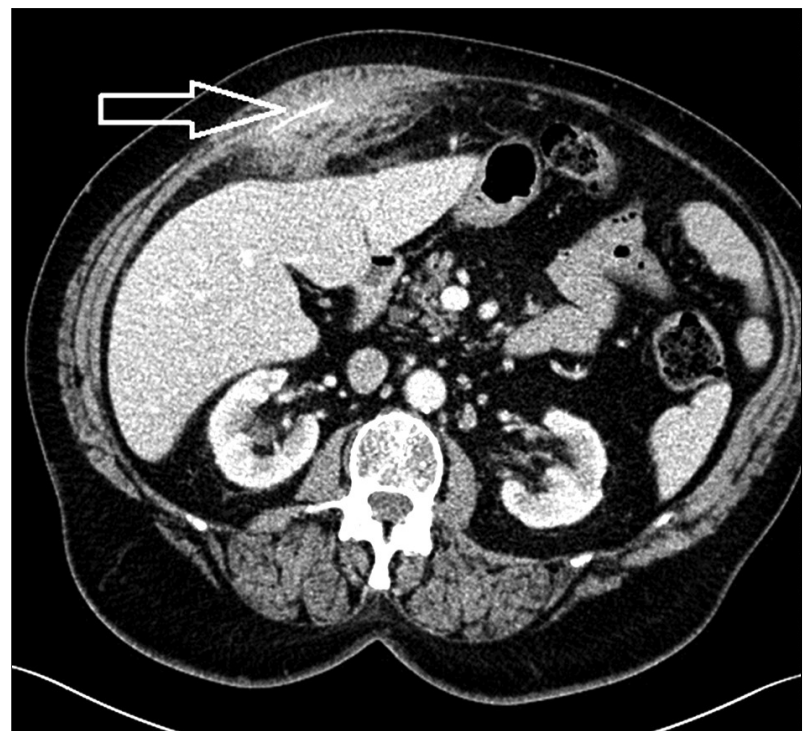

Figure 1. Axial contrast-enhanced CT scan of the abdomen - an abdominal wall inflammatory mass with linear contrast enhancement - foreign body (arrow), an infiltration of the inflammatory lesion of the transverse colon and the right lobe of the liver is also visualized

anterior abdominal wall, the rectus abdominis muscle, the greater omentum, and the transverse colon with healed perforation was revealed. We performed en block tumor excision with partial resection of the transverse colon with an end-to-end anastomosis (Fig. 2). We found a fishbone inside the mass (Fig. 3). The histopathological examination showed the inflammatory purulent lesion with central necrosis containing pus and actinomycotic cells (Fig. 4). The patient received parenteral crystalline penicillin treatment and went on to make a full recovery.

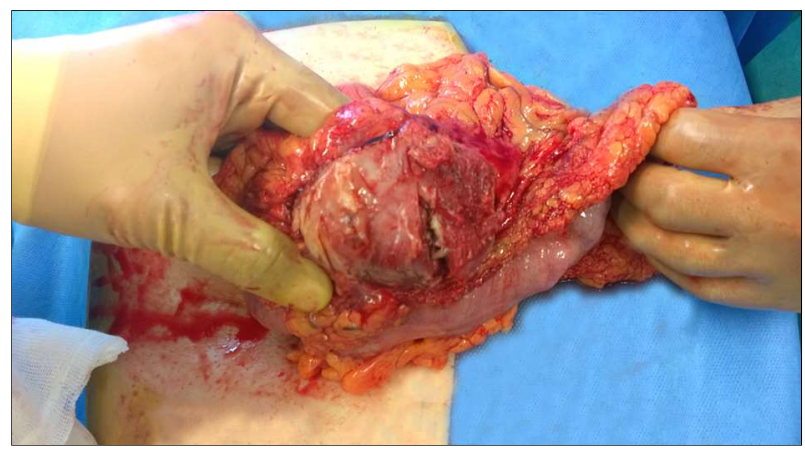

Figure 2. Intraoperative view of en block tumor excision showing a lesion infiltrating the greater omentum and the transverse colon 


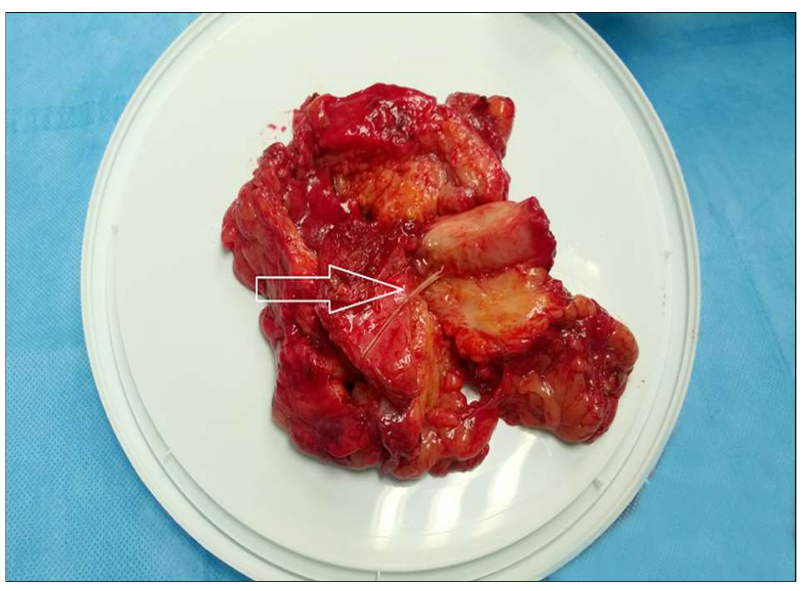

Figure 3. The inflammatory tumor mass after resection containing a fishbone inside (arrow)

The woman was discharged on the $11^{\text {th }}$ postoperative day.

\section{Discussion}

This case shows diagnostic difficulties with an occulted perforation of a gastrointestinal tract complicated abdominal actinomycosis.

Nearly $80 \%$ of foreign bodies pass through the digestive system naturally and do not require any intervention (8).

Perforation of the gastrointestinal tract is one possible complication. It is estimated that $<1 \%$ of foreign bodies will perforate the bowel (9). In such a case, non-specific symptoms may occur and setting the correct diagnosis might be delayed. The most frequent cause of intestinal perforation is fishbone ingestion (10). Anatomical angulations and narrowing of gastrointestinal tract are typical sites of penetration. Studies have shown that over $80 \%$ perforations occur in the ileocecal region, the second typical place is the rectosigmoid junction (4). An interruption of continuous bowel wall may lead to local or diffuse infection within peritoneum or retroperitoneum space. Naturally occurring intestinal microorganism can lead to bacterial abscess or peritonitis. Actinomyces species are endogenous inhabitants of most human mucous membranes. A mucosal injury may be a first step preceding actinomyceal infection (11). The

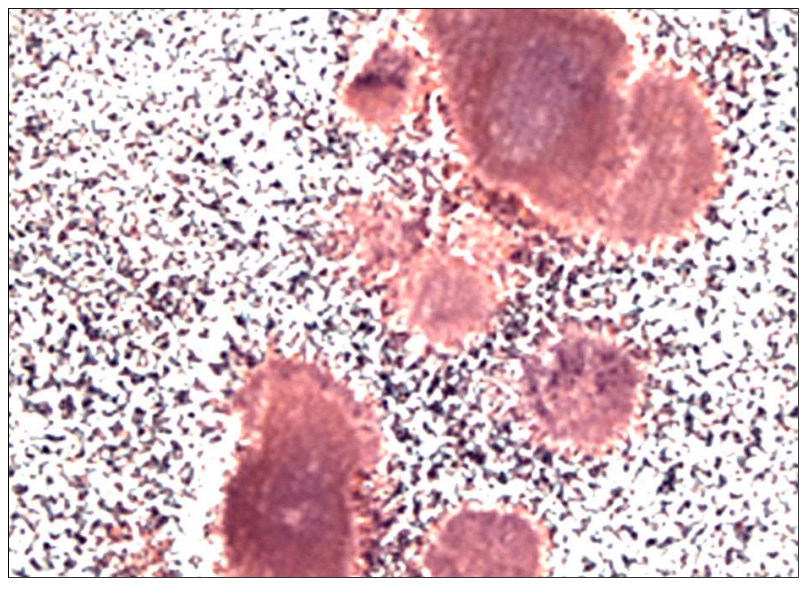

Figure 4. Histopathology of the tumor - filamentous actinomyces colonies with surrounding chronic inflammatory cells (hematoxylin-eosin stain H\&E, original magnification x100)

abdominal actinomycosis is manifested by abscess that can be followed by external and internal fistula formation. Our patient presented with anterior abdominal wall mass tenderness without skin discoloration. Symptoms were unusual and the differential diagnosis included malignancy, especially, since the blood tests did not indicate inflammatory process. Less than $10 \%$ actinomycosis are diagnosed prior to surgery (11).

In such cases radiological imaging, such as USG, is useful for investigation. Radiological imagining allows for visualization of an abdominal mass with internal content, the extent of the inflammatory process, and degree of organ involvement. In this case, a contrastenhanced CT that revealed the presence of a foreign body inside the lesion was valuable and allowed to accurately determine the size of the tumor and its local advancement. Appropriate surgical treatment was performed due to imaging. Specific signs for abdominal actinomycosis on CT scanning were reported such as colonic thickening and mass formation with extensive infiltration (12).

Actinomyces are an obligate anaerobe that must be cultured on selective medium, rich in carbon dioxide (7). For this reason a definitive diagnosis is easier to obtain by finding characteristic morphological signs in microscopic view received from needle aspiration of a collection or from a surgical specimen (13). 
Actinomyces are sensitive to penicillin. The first line of the optimal therapeutic regimen requires 2.5-5 million units, administrated parenterally four times daily (5). Antibiotic treatment duration should be individualized depending on whether it is single or an adjuvant treatment method. Our patient received parenteral penicillin $\mathrm{G}$ (5 million units four times per day) on the fourth day after surgery when final diagnosis was confirmed by the histopathological results. After seven days, the treatment was modified to oral penicillin $\mathrm{V}$ (1.5 million units three times per day) continued for the next eight days. The prognosis is favorable in more than $90 \%$ cases of abdominal actinomycosis after medical and surgical therapy (14).

\section{Conclusion}

In conclusion, an abdominal actinomycosis is a very rare diagnostic finding, commonly associated with migration of foreign body. It should be considered in patients admitted for an indolent course of the disease and nonspecific abdominal symptoms. Diagnosis of actinomycosis is difficult and requires an adequate specimen for histopathological examination. Surgical treatments of abdominal actinomycosis combined with antibiotics are very effective.

\section{Conflict of Interest}

The authors have no financial conflicts of interest.

\section{References}

1. Ikenberry SO, Jue TL, Anderson MA, Appalaneni V, Banerjee S, BenMenachem T, et al. Management of ingested foreign bodies and food impactions. Gastrointestinal Endoscopy. 2011;73(6):1085-91.

2. Hakeem A, Shanmugam V, Badrinath K, Dube M, Panto P. Delay in diagnosis and lessons learnt from a case of abdominal wall abscess caused by fishbone perforation. Annals of the Royal College of Surgeons of England. 2015;97(3):E39-E42.

3. Ambrosi A, Prete FP, Neri V, lerardi E. Pseudotumoural lesion of the abdominal wall due to a fishbone migration. Digestive and Liver Disease. 2007:39(4):368

4. Beecher SM, O'Leary DP, McLaughlin R. Diagnostic dilemmas due to fish bone ingestion: Case report \& literature review. Int J Surg Case Rep. 2015;13:112-5.

5. Wong VK, Turmezei TD, Weston VC. Actinomycosis. BMJ. 2011;343:d6099.

6. Filipovic B, Milinic N, Nikolic G, Randelovic T. Primary actinomycosis of the anterior abdominal wall: Case report and review of the literature. J Gastroenterol Hepatol. 2005;20(4):517-20.

7. Garner J, Macdonald M, Kumar P. Abdominal actinomycosis. Int J Surg. 2007;5(6):441-8

8. Malick KJ. Endoscopic Management of Ingested Foreign Bodies and Food Impactions. Gastroenterology Nursing. 2013;36(5):359-65.

9. Goh BKP, Chow PKH, Quah HM, Ong HS, Eu KW, Ooi L, et al. Perforation of the gastrointestinal tract secondary to ingestion of foreign bodies. World Journal of Surgery. 2006;30(3):372-7.

10. Choi Y, Kim G, Shim C, Kim D. Peritonitis with small bowel perforation caused by a fish bone in a healthy patient. World Journal of Gastroenterol. 2014;20(6):1626-9.

11. Choi MM, Beak JH, Lee JN, Park S, Lee WS. Clinical features of abdominopelvic actinomycosis: report of twenty cases and literature review. Yonsei Med J. 2009;50(4):555-9.

12. Lee IJ, Ha HK, Park CM, Kim JK, Kim JH, Kim TK, et al. Abdominopelvic actinomycosis involving the gastrointestinal tract: CT features. Radiology. 2001;220(1):76-80

13. Liu K, Joseph D, Lai K, Kench J, Ngu MC. Abdominal actinomycosis presenting as appendicitis: two case reports and review. J Surg Case Rep. 2016;2016(5):rjw068.

14. Delogu L, Paliogiannis P, Fara A, Cossu A, Scognamillo F, Attene F. Actinomycotic lleal Perforation: A Case Report and Literature Review. Acta Medica Mediterranea. 2013;29(4):741-4. 